\title{
PERBANDINGAN KEMAMPUAN BERPIKIR KRITIS MATEMATIS ANTARA SISWA YANG BELAJAR MENGGUNAKAN MODEL PROBLEM BASED LEARNING DAN MODEL RECIPROCAL TEACHING
}

\author{
Mezika Wahyuni, Wardani Rahayu, Ratna Widyati \\ Program Studi Pendidikan Matematika, FMIPA UNJ
}

\begin{abstract}
Abstrak
Penelitian ini bertujuan untuk mengetahui model pembelajaran yang sesuai untuk meningkatkan kemampuan berpikir kritis matematis siswa dengan membandingkan model pembelajaran Problem Based Learning dan Reciprocal Teaching.

Penelitian ini dilakukan pada siswa kelas VIII di SMP Negeri 149 Jakarta semester genap tahun ajaran 2015/2016. Metode penelitian yang digunakan adalah quasi experiment. Teknik pengambilan sampel menggunakan teknik Multistage Random Sampling dan teknik purposive sampling. Kedua kelas eksperimen yang dipilih berasal dari populasi yang berdistribusi normal, memiliki varians yang homogen dan mempunyai kesamaan rata-rata. Instrumen penelitian yang digunakan adalah tes kemampuan berpikir kritis matematis sebanyak 4 soal uraian. Instrumen tersebut telah melalui uji validitas isi, validitas konstruk dan validitas empirik. Perhitungan reliabilitas dilakukan dengan menggunakan Cronbach's Alpha dan diperoleh koefisien reliabilitas sebesar 0.4267 dengan kategori cukup.

Berdasarkan data hasil penelitian, kelas eksperimen I (Model Problem Based Learning) dan kelas eksperimen II (Model Reciprocal Teaching) berdistribusi normal dan memiliki varians yang sama. Pengujian hipotesis dilakukan dengan menggunakan statistik uji-t pada taraf signifikansi $\alpha=0,05$. Berdasarkan hasil perhitungan, diperoleh $t_{\text {hitung }}=2,0440, d k=69$ dan $t_{\text {tabel }}=1,6672$ sehingga $t_{\text {hitung }}>t_{\text {tabel }}$, maka $H_{0}$ ditolak. Dengan demikian dapat disimpulkan bahwa kemampuan berpikir kritis matematis siswa yang belajar menggunakan model Problem Based Learning lebih tinggi daripada siswa yang menggunakan model Reciprocal Teaching.
\end{abstract}

Kata Kunci: Kemampuan Berpikir Kritis Matematis, Model Problem Based Learning, Model Reciprocal Teaching

\section{Abstract}

The purpose of this study was to determine learning model that increase student's ability in critical thinking of mathematics by comparison between Problem Based Learning and Reciprocal Teaching.

The population of this study was student of grade VIII SMP Negeri 149 Jakarta in second half academic year 2015/1026. This research method is a quasi experimental. The experiment classes are chosen from population that has similar abilities. The instrument is four questions that measure student's ability in critical thinking mathematics. The instrument was validated in content validity, construct validity and empiric validity. The reliability used Cronbach's Alpha and the result is 0,4267in sufficient category.

The result showed that the data of two classes have a normal distribution and same variance. Hypothesis testing used $\alpha=0,05$. Based on the calculation, $t_{\text {hitung }}=2,0440, d k=69$ and $t_{\text {tabel }}=1,6672$, so $t_{\text {hitung }}>$ $t_{\text {tabel }}$ that mean $H_{0}$ was rejected. So the conclusion is learning using Problem Based Learning model increase student's ability in critical thinking mathematic higher than Reciprocal Teaching model.

Keyword: critical thinking ability of mathematics, Problem Based Learning model, Reciprocal Teaching model

\section{PENDAHULUAN}

\section{A. Latar Belakang}

Matematika merupakan ratu dari ilmu pengetahuan yang diperlajari di semua tingkat pendidikan dan oleh semua orang. Matematika merupakan suatu alat untuk mengembangkan kemampuan berpikir. Pembelajaran matematika di sekolah dirasa kurang bermakna bagi siswa karena siswa dalam hal mengembangkan kemampuan berpikir kritis siswa. Hal ini terlihat pada pembelajaran matematika di sekolah dimana siswa diberikan materi oleh guru tanpa memberikan 
kesempatan bagi siswa untuk mengemukakan ide dan pengetahuan yang dimilikinya. Pembelajaran di sekolah berpusat pada guru, dimana guru menjadi pusat informasi dan siswa mendengarkan. Hal ini mengakibatkan kemampuan berpikir kritis siswa tidak berkembang.

Berdasarkan hasil Programme International Student Assessment (PISA) 2012, Indonesia berada pada posisi ke 64 dari 65 negara yang berpartisipasi dalam tes bidang matematika dan IPA. Survei yang dilakukan oleh Trends in International Mathematics and Science Study (TIMSS) menunjukkan bahwa siswa Indonesia berada pada ranking yang amat rendah dalam beberapa kategori, seperti memahami informasi yang kompleks, memahami teori, analisis dan pemecahan masalah, serta dalam investigasi ilmu.

Salah satu kemampuan yang penting dimiliki oleh siswa adalah kemampuan berpikir kritis matematis. Kemampuan berpikir kritis matematis sangat diperlukan agar siswa dapat mengembangkan konsep dan pengetahuan yang dimilikinya untuk memecahkan suatu masalah. Kemampuan berpikir kritis matematis siswa tidak berkembang dikarenakan oleh beberapa faktor salah satunya yaitu model pembelajaran yang digunakan kurang tepat sehingga tidak mendorong siswa untuk mengembangkan kemampuan berpikir kritisnya.

Model pembelajaran yang dapat meningkatkan kemampuan berpikir kritis matematis diantaranya model Problem Based Learning dan model Reciprocal Teaching. Langkah-langkah dalam model pembelajaran ini dapat meningkatkan kemampuan berpikir kritis siswa.

Berdasarkan uraian diatas, maka perlu diadakan penelitian lebih lanjut, salah satunya mengenai "Perbandingan Kemampuan Berpikir Kritis Matematis antara Siswa yang Belajar Menggunakan Model Problem Based Learning dan Model Reciprocal Teaching."

\section{B. Identifikasi Masalah}

Berdasarkan latar belakang yang telah dipaparkan sebelumnya maka dapat diidentifikasikan masalahnya adalah sebagai berikut:

1. Mutu pendidikan di Indonesia perlu ditingkatkan

2. Minat dan prestasi belajar siswa yang menurun.

3. Kemampuan berpikir kritis siswa yang rendah.

4. Penerapan model Problem Based Learning dapat meningkatkan kemampuan berpikir kritis matematis siswa.

5. Penerapan model Reciprocal Teaching dapat meningkatkan kemampuan berpikir kritis matematis siswa.

6. Penerapan model Problem Based Learning dan model Reciprocal Teaching meningkatkan kemampuan berpikir kritis matematis siswa yang mungkin berbeda.

\section{Pembatasan Masalah}

Permasalahan yang akan dibahas pada penelitian ini dibatasi pada perbandingan kemampuan berpikir kritis matematis siswa yang menggunakan model Problem Based Learning dengan model Reciprocal Teaching

\section{Perumusan Masalah}

Berdasarkan identifikasi dan pembatasan masalah yang telah diuraikan di atas, maka masalah utama yang dirumuskan dalam penelitian ini adalah "apakah terdapat perbedaan kemampuan berpikir kritis matematis antara siswa yang belajar menggunakan model Problem Based Learning dan Reciprocal Teaching?"

\section{E. Tujuan}

Berdasarkan rumusan masalah yang telah dikemukakan di atas, maka tujuan yang ingin dicapai dalam penelitian ini adalah untuk mengetahui perbandingan kemampuan berpikir kritis matematis siswa yang belajar menggunakan model Problem Based Learning dan model Reciprocal Teaching.

\section{F. Manfaat}

Hasil penelitian ini diharapkan memberikan manfaat yaitu sebagai berikut :

1. Bagi siswa adalah agar dapat meningkatkan kemampuan berfikir kritis matematis siswa dengan pembelajaran yang efektif dan bermakna. 
2. Bagi guru adalah untuk memperoleh informasi dalam melaksanakan pembelajaran matematika di sekolah dengan model pembelajaran yang bervariasi untuk meningkatkan kemampuan berpikir kritis matematika siswa.

3. Bagi sekolah adalah untuk memberikan sumbangan yang baik dalam rangka meningkatkan kemampuan berpikir kritis matematis siswa pada pembelajaran matematika.

\section{KAJIAN PUSTAKA}

\section{A. Deskripsi Teori}

\section{Kemampuan Berpikir Kritis Matematis}

Berpikir kritis merupakan salah satu proses berpikir tingkat tinggi yang dapat digunakan dalam pembentukan sistem konseptual siswa. Berpikir kritis dalam matematika menurut Krulik dan Rudnick (dalam NCTM, 2000) adalah berpikir yang menguji, mempertanyakan, menghubungkan, mengevaluasi semua aspek yang ada dalam suatu situasi ataupun masalah. Berpikir kritis harus melalui beberapa tahapan untuk sampai kepada sebuah kesimpulan atau penilaian.

Kemampuan berpikir kritis matematis siswa dapat dicapai dengan memperhatikan indikatorindikator, seperti memberikan penjelasan sederhana, memberikan kesimpulan,memberikan penjelasan lebih lanjut dan menentukan strategi dan taktik yang tepat. Kemampuan berpikir kritis siswa akan berkembang apabila diberikan permasalahan/materi yang mencakup keempat indikator tersebut.

\section{Model Problem Based Learning}

Model Problem Based Learning adalah model pembelajaran yang dimulai dengan pemberian masalah otentik dari kehidupan nyata yang tidak terstruktur kepada siswa. Duch (dalam Shoimin, 2014) berpendapat bahwa Problem Based Learning adalah model pembelajaran yang bercirikan adanya masalah sebagai konteks untuk peserta didik belajar berpikir kritis dan keterampilan memecahkan masalah serta memperoleh pengetahuan.

Model pembelajaran Problem Based Learning dapat mengembangkan kemampuan berpikir kritis siswa pada saat siswa diberikan masalah yang membutuhkan pemikiran secara mendalam, kemudian siswa bersama dnegan kelompok memecahkan masalah yang telah diberikan kepada mereka. Sehingga model ini dapat dijadikan sebagai suatu alternatif model pembelajaran yang dapat meningkatkan kemampuan berpikir kritis siswa.

\section{Model Reciprocal Teaching}

Reciprocal Teaching adalah model pembelajaran berupa kegiatan mengajarkan materi kepada teman. Model pembelajaran ini harus memperhatikan tiga hal yaitu siswa belajar mengingat, berpikir dan memotivasi diri. Kegiatan pembelajaran dengan menggunakan model Reciprocal Teaching dimulai dengan pemberian naskah matematika yang kemudian akan didiskusikan bersama dengan kelompok. Model pembelajaran ini akan memupuk rasa percaya diri siswa untuk menyampaikan pendapat di depan kelas.

Pendapat Palinscar (dalam Shoimin, 2014) model Reciprocal Teaching mengandung empat strategi, yaitu question generating, clarifying, predicting, dan summarizing. Question generating merupakan tahap dimana siswa diberikan kesempatan untuk membuat pertanyaan. Clarifying merupakan stategi dimana siswa dapat bertanya kepada guru. Predicting pada strategi ini siswa membuat hipotesis atau perkiraan mengenai konsep berikutnya. Summarizing merupakan strategi terakhir dimana siswa diberi kesempatan untuk mengidentifikasikan dan mengintegrasikan informasi-informasi yang terkandung dalam materi.

\section{B. Penelitian yang Relevan}

Penelitian Hastuti yang berjudul "Peningkatan Kemampuan Berpikir Kritis Matematis Siswa SMP melalui Pembelajaran Berbasis Masalah", hasil penelitian menunjukkan bahwa kemampuan berpikir kritis matematis siswa meningkat melalui penerapan model Problem Based Learning. Sedangkan menurut penelitian Karim yang berjudul "Meningkatkan Kemampuan Berpikir Kritis 
melalui Model Recprocal Teaching", menunjukkan bahwa kemampuan berpikir kritis siswa meningkat dengan penerapan model Reciprocal Teaching.

\section{Kerangka Berpikir}

Pembelajaran matematika yang terjadi di sekolah pada umumnya masih berupa pembelajaran konvensional yang bersifat teacher centered, dimana guru bertindak sebagai pusat pemberi informasi kepada siswa. Pembelajaran matematika di sekolah hanya berupa pemberian materi yang diberikan oleh guru, dengan pemberian contoh dan latihan soal dengan menggunakan langkah-langkah penyelesaian yang diberikan atau dicontohkan oleh guru tanpa memberi kesempatan kepada siswa untuk dapat memecahkan soal tersebut dengan ide sendiri.

Salah satu faktor penyebab rendahnya kemampuan berpikir kritis matematis siswa dikarenakan pada proses pembelajaran matematika di sekolah, siswa hanya dijadikan objek pembelajaran yang pasif. Dalam pembelajaran di sekolah guru tidak memberikan kesempatan kepada siswa dalam mengembangkan kemampuan berpikir kritis siswa.

Solusi yang dapat dikembangkan untuk meningkatkan kemampuan berpikir kritis matematis siswa adalah dengan menerapkan metode pembelajaran yang bersifat student centered (pembelajaran yang berpusat kepada siswa). Pada pembelajaran student centered siswa diberikan kesempatan dalam menyelesaikan masalah dengan cara sendiri atau dengan menggunakan kemampuan yang dimilikinya. Siswa dapat mengemukakan gagasan dan menerima gagasan orang lain. Model pembelajaran yang bersifat student centered adalah model Problem Based Learning dan model Reciprocal Teaching, dimana pada kedua model pembelajaran ini guru hanya bersifat sebagai fasilitator dan bukan menjadi satu-satunya pusat informasi, siswa juga bisa belajar dari buku dan lingkungan sekitar.

Model Problem Based Learning dan model Reciprocal Teaching memiliki landasan filosofi yang sama, yaitu konstruktivisme. Model Problem Based Learning dan model Reciprocal Teaching menekankan kepada bagaimana siswa mengkonstruksi pengetahuan yang telah diperoleh sebelumnya untuk dapat menyelesaikan suatu permasalahan matematika yang diberikan oleh guru.

Model Problem Based Learning (PBL) adalah suatu model pembelajaran yang ditekankan terhadap penyelesaian suatu permasalahan kehidupan sehari hari yang tidak terstruktur untuk diselesaikan secara kelompok. Pemberian permasalahan kehidupan sehari-hari dimaksudkan agar siswa mengetahui hubungan antara pengetahuan yang dimilikinya dengan penerapannya dalam kehidupan sehari-hari, sehingga pembelajaran matematika lebih terasa bermakna bagi siswa. Terlebih lagi dengan memberikan permasalahan yang tidak terstruktur untuk dapat membuat siswa berpikir lebih dalam untuk dapat menyelesaikan permasalahan tersebut. Penyelesaian permasalahan di dalam kelompok menjadi proses saling bertukar pikiran antar siswa. Siswa didalam kelompok didorong untuk mencari solusi permasalahan, menganalisa, lalu mencoba menerapkan strategi yang dapat digunakan untuk menyelesaikan permasalahan tersebut tersebut berdasarkan pengetahuan yang dipelajari. Hasil penyelesaian masing-masing kelompok dibahas dan dievaluasi oleh guru bersama dengan siswa untuk mengetahui jawaban yang sebenarnya.

Model Reciprocal Teaching adalah model pembelajaran dimana siswa belajar sendiri dengan membuat rangkuman dari apa yang mereka pelajari. Model Reciprocal Teaching adalah suatu model yang dirancang untuk memberikan manfaat agar tujuan pembelajaran tercapai dan meningkatkan kemampuan siswa memahami apa yang dibaca. Sehingga model Reciprocal Teaching dapat meningkatkan kemampuan berpikir kritis matematis siswa karena siswa didorong untuk memahami sendiri apa yang dibacanya.

Terdapat perbedaan antara model Problem Based Learning dengan model Reciprocal Teaching. Siswa pada model Problem Based Learning diberikan suatu permasalahan kehidupan sehari-hari yang tidak terstruktur. Sedangkan pada model Reciprocal Teaching siswa diberikan bahan ajar dan siswa diminta untuk meringkas dan memahami isi materi yang diberikan.

Perbedaan yang mendasar antara model Problem Based Learning dengan model Reciprocal Teaching terletak pada tujuan. Tujuan dari pembelajaran dengan model Problem Based Learning 
adalah meningkatkan kemampuan berpikir kritis, analitis, sistematis dan logis. Model Problem Based Learning mengharuskan guru agar dapat meningkatkan kemampuan beripikir kritis, analitis, sistematis dan logis siswa. Sedangkan model Reciprocal Teaching bertujuan untuk meningkatkan keterampilan memahami isi bacaan dan meningkatkan kemampuan komunikasi siswa. Model Reciprocal Teaching mendorong siswa untuk memahami sendiri materi yang diberikan guru. Kemudian siswa mencoba menerapkan konsep yang diperoleh dalam memecahkan masalah matematika sehingga siswa dapat melatih kemampuan berpikir kritis dalam menyelesaikan masalah matematika. Berdasarkan hal tersebut, diduga kemampuan berpikir kritis matematis siswa yang menggunakan model Problem Based Learning akan lebih tinggi daripada siswa yang menggunakan model Reciprocal Teaching.

\section{Hipotesis Penelitian}

Berdasarkan deskripsi teori dan kerangka berpikir di atas, maka hipotesis yang diajukan dalam penelitian ini adalah kemampuan berpikir kritis matematis siswa yang belajar menggunakan model Problem Based Learning lebih tinggi daripada siswa yang belajar menggunakan model Reciprocal Teaching.

\section{METODOLOGI PENELITIAN}

\section{A. Tempat dan Waktu Penelitian}

Penelitian ini dilakukan di SMP Negeri 149 Jakarta semester genap tahun pelajaran 2015/2016 pada pokok garis singgung lingkaran.

\section{B. Metode Penelitian}

Penelitian ini merupakan penelitian kuantitatif dengan metode penelitian yang digunakan adalah metode quasi experiment atau eksperimen semu. Metode ini digunakan karena tidak memungkinkan peneliti sepenuhnya untuk mengontrol variabel-variabel luar yang mempengaruhi pelaksanaan eksperimen.

\section{Desain Penelitian}

Desain penelitian ini menggunakan dua kelas sebagai kelas eksperimen. Kelas eksperimen I adalah kelas yang belajar menggunakan model pembelajaran AIR, sedangkan kelas ekpserimen II adalah kelas yang belajar menggunakan model pembelajaran SFE. Adapun desain dalam penelitian ini adalah :

Tabel 3.1 Desain Penelitian

\begin{tabular}{|c|c|c|c|}
\hline & Kelas & Perlakuan & Tes \\
\hline$R$ & $E_{1}$ & $X_{E_{1}}$ & $Y$ \\
\hline$R$ & $E_{2}$ & $X_{E_{2}}$ & $Y$ \\
\hline
\end{tabular}

Keterangan:

$E_{1} \quad=$ Kelas eksperimen 1, yaitu kelas yang belajar menggunakan model Problem Based Learning

$E_{2} \quad=$ Kelas eksperimen 2, yaitu kelas yang belajar menggunakan model Reciprocal Teaching

$X_{E_{1}} \quad=$ Perlakuan pada kelas eksperimen 1 (model Problem Based Learning)

$X_{E_{2}} \quad=$ Perlakuan pada kelas eksperimen 2 (model Reciprocal Teaching)

$Y \quad=$ Rata-rata tes akhir pada kelas eksperimen setelah diberikan perlakuan

$R \quad=$ =Pengambilan sampel secara random

D. Populasi dan Sampel

Populasi target pada penelitian ini adalah seluruh siswa SMP Negeri 149 Jakarta pada semester genap tahun pelajaran 2015/2016. Kemudian populasi terjangkaunya adalah seluruh siswa kelas VIII SMP Negeri 74 Jakarta tahun pelajaran 2015/2016. Sampel penelitian diperoleh dengan teknik Multistage Random Sampling. Dengan menggunakan teknik purposive sampling, dari 8 kelas VIII akan dipilih kelas-kelas yang diajarkan oleh guru yang sama. 
Dengan memilih dua kelas dari empat kelas yang diajarkan oleh guru yang sama, pengambilan sampel dilakukan secara acak. Sebelum memberikan perlakuan berbeda kepada kedua kelas, terlebih dahulu dilakukan uji normalitas, uji homogenitas serta uji kesamaan rata-rata untuk mengetahui kemampuan awal keempat kelas tersebut. Dua kelas yang diajar oleh guru yang sama dan memiliki kemampuan awal yang sama akan dijadikan sebagai kelas eksperimen. Kelas eksperimen I akan diberikan perlakuan dengan menggunakan model Problem Based Learning, sedangkan kelas eksperimen II akan diberikan perlakuan dengan menggunakan model Reciprocal Teaching.

\section{E. Teknik Pengumpulan Data}

Penelitian ini menggunakan teknik pengumpulan data yaitu tes. Tes yang digunakan adalah tes kemampuan berpikir kritis matematis dengan soal berbentuk uraian dan tes dilakukan setelah perlakuan diberikan kepada kedua kelas eksperimen.

\section{F. Instrumen Penelitian}

Instrumen penelitian yang digunakan dalam penelitian ini berbentuk tes uraian. Tes uraian tersebut bertujuan untuk mengetahui kemampuan berpikir kritis matematis siswa setelah pembelajaran dilakukan pada kedua kelas. Soal-soal tes mengacu kepada indikator kemampuan berpikir kritis matematis. Bahan tes diambil dari materi pelajaran matematika kelas VIII SMP pada pokok bahasan garis singgung lingkaran. Tes berupa soal cerita yang memuat keempat indikator kemampuan berpikir kritis matematis.

Sebelum penelitian ini dilakukan, instrumen akan diujicobakan terlebih dahulu agar mendapatkan alat evaluasi yang berkualitas baik. Alat evaluasi yang baik dalam penelitian ini dilihat dari uji instrumen, yaitu validitas dan reliabilitas. Dari empat soal yang diberikan kepada validator ahli, yakni dua dosen pendidikan matematika UNJ, keempat soal tersebut dinyatakan memiliki validitas isi dan validitas konstruk. Hasil Pengujian validitas empirik, keempat soal yang diberikan dinyatakan keempat soal dinyatakan valid dan kemudian dihitung reliabilitasnya. Hasil pengujian reliabilitas terhadap keempat soal tes kemampuan berpikir kritis matematis diperoleh $\alpha=0.4267$, maka instrumen dinyatakan cukup reliabel dan dapat digunakan sebagai alat ukur kemampuan berpikir kritis matematis siswa.

G. Hipotesis Statistik

Hipotesis pada penelitian ini dirumuskan sebagai berikut:

\section{H. Teknik Analisis Data}

$$
\begin{aligned}
& H_{0}: \mu_{1} \leq \mu_{2} \\
& H_{1}: \mu_{1}>\mu_{2}
\end{aligned}
$$

\section{Uji Persyaratan Analisis Data}

Sebelum dilakukan pengujian hipotesis, terlebih dahulu dilakukan pengujian persyaratan analisis untuk mengetahui keadaan awal kelas yang akan dipilih sebagai sampel. Uji yang dilakukan adalah uji normalitas menggunakan uji Liliefors, uji homogenitas menggunakan uji Bartlet dan uji kesamaan rata-rata menggunakan ANAVA satu arah. Dari keempat kelas yang diuji, diperoleh hasil bahwa data keempat kelas berasal dari kondisi awal yang sama. Maka dipilih dua kelas untuk dijadikan kelas eksperimen, yaitu kelas VIII A dan VIII D.

\section{Uji Hipotesis}

Setelah diperoleh data setelah perlakuan, maka akan dilakukan uji hipotesis. Namun sebelumnya perlu dilakukan uji persyaratan untuk uji hipotesis. Uji tersebut adalah uji normalitas menggunakan uji Lilliefors dan uji homogenitas menggunakan uji Fisher. Data hasil perlakuan diperoleh bahwa data kedua kelas berdistribusi secara normal dan memiliki varians yang sama. Maka dari itu, pengujian hipotesis dengan uji- $t$ akan menggunakan rumus uji untuk varians yang sama.

\section{HASIL PENELITIAN DAN PEMBAHASAN \\ A. Deskripsi Data}


Data dalam penelitian ini adalah nilai tes kemampuan berpikir kritis matematis siswa pada pokok bahasan garis singgung lingkaran di kelas VIII SMP Negeri 149 Jakarta. Data yang diperoleh berasal dari 71 siswa, yang terdiri dari 35 siswa kelas eksperimen I (model Problem Based Learning) dan 36 siswa kelas eksperimen II (model Reciprocal Teaching). Statistik deskriptif dari hasil tes kemampuan komunikasi matematis kedua kelas eksperimen disajikan dalam tabel berikut.

\begin{tabular}{|l|l|l|}
\hline Statistik & Kelas Eksperimen I & Kelas Eksperimen II \\
\hline Banyak siswa & 35 & 36 \\
\hline Nilai maksimum & 92 & 83 \\
\hline Nilai minimum & 42 & 42 \\
\hline Modus & 75 dan 83 & 75 \\
\hline Median & 75 & 71 \\
\hline Rata-rata (mean) & 73,5429 & 67,3056 \\
\hline Ragam (varians) & 152,9613 & 177,1897 \\
\hline Simpangan Baku & 12,36775 & 13,3113 \\
\hline
\end{tabular}

Berdasarkan tabel diatas, dapat dilihat bahwa kemampuan berpikir kritis matematis siswa kelas eksperimen I lebih tinggi daripada kelas eksperimen II. Hal ini ditunjukkan dari nilai ratarata kelas eksperimen I, yaitu 73,5429 yang lebih tinggi dari nilai rata-rata kelas eksperimen II, yaitu 67,3056.

\section{B. Pengujian Persyaratan Analisis Data}

Sebelum dilakukan pengujian hipotesis, terlebih dahulu dilakukan pengujian prasyarat analisis data sebagai syarat pengujian hipotesis. Uji prasyarat analisis data yang dilakukan adalah uji normalitas dan uji homogenitas. Data yang digunakan adalah hasil tes kemampuan berpikir kritis matematis siswa pada pokok bahasan garis singgung lingkaran.

Hasil perhitungan untuk uji normalitas kelas eksperimen I $L_{\text {hitung }}=0,1079$ dan $L_{\text {tabel }}=$ 0,1498 pada taraf signifikansi $\alpha=0,05$ untuk $\mathrm{n}=35$. Berdasarkan hasil perhitungan tersebut dilihat bahwa $L_{0}<L_{\text {tabel }}$, maka $\mathrm{H}_{0}$ diterima sehingga dapat disimpulkan bahwa kelas eksperimen I memiliki data hasil tes kemampuan berpikir kritis matematis yang berdistribusi normal. Kelas eksperimen II Hasil perhitungan untuk kelas eksperimen II diperoleh $L_{\text {hitung }}=0,1192$ dan $L_{\text {tabel }}=0,1477$ pada taraf signifikansi $\alpha=0,05$ dan $\mathrm{n}=36$. Berdasarkan hasil perhitungan tersebut dilihat bahwa $\mathrm{L}_{0}<\mathrm{L}_{\text {tabel }}$, maka $\mathrm{H}_{0}$ diterima sehingga dapat disimpulkan bahwa kelas eksperimen II memiliki kemampuan berpikir kritis matematis yang berdistribusi normal.

Uji homogenitas berdasarkan hasil perhitungan, didapat $F_{\text {hitung }}=1,1584$ dan $F_{\frac{\alpha}{2}\left(n_{1}-1, n_{2}-1\right)}=1$,9678. Dengan demikian, dapat disimpulkan bahwa $F_{\text {hitung }}<F_{\frac{\alpha}{2}\left(n_{1}-1, n_{2}-1\right)}{ }^{\prime}$ maka $\mathrm{H}_{0}$ diterima yang berarti data hasil tes kemampuan berpikir kritis matematis kedua kelas eksperimen memiliki varians yang sama (homogen). Hal ini berarti dalam melakukan pengujian hipotesis, uji- $t$ yang digunakan adalah statistik uji- $t$ dengan varians yang sama.

\section{Pengujian Hipotesis}

Berdasarkan hasil perhitungan diperoleh nilai $t_{\text {hitung }}=2,044$ dan $t_{\text {tabel }}=1,6672$. Jadi $t_{\text {hitung }}>t_{\text {tabel }}$, maka $\mathrm{H}_{0}$ ditolak yang berarti kemampuan berpikir kritis matematis kelas eksperimen I (siswa yang menggunakan model Problem Based Learning) lebih tinggi daripada kelas eksperimen II (siswa yang menggunakan model Reciprocal Teaching).

\section{Pembahasan}

Berdasarkan hasil pengujian hipotesis di atas, diperoleh kesimpulan bahwa kemampuan berpikir kritis matematis siswa yang belajar menggunakan model Problem Based Learning lebih tinggi daripada siswa yang belajar menggunakan model Reciprocal Teaching. Hal ini dikarenakan siswa diberikan kesempatan lebih untuk mengalami dan mengonstruksi ide-ide dan pengetahuan yang telah mereka miliki dalam menyelesaikan suatu permasalahan matematika yang tidak 
terstruktur. Kegiatan ini dapat membuat siswa menjadi lebih baik dalam bernalar dan berpikir karena masalah yang diberikan menuntut siswa berargumentasi pada setiap langkah yang dikerjakannya.

Rendahnya rata-rata hasil tes kemampuan berpikir kritis matematis kedua kelas eksperimen disebabkan karena tidak semua siswa terlibat dalam setiap bagian pembelajaran dari model Problem Based Learning dan model Reciprocal Teaching. Misal pada saat diskusi kelompok terdapat beberapa kelompok yang anggotanya tidak berpartisipasi dalam kegiatan diskusi, sehingga siswa tersebut tidak memahami materi yang dipelajari secara optimal. Kontrol guru sangat diperlukan agar seluruh siswa dapat berpartisipasi aktif dalam proses pembelajaran matematika di kelas.

Penyebab lain rendahnya rata-rata hasil tes kemampuan berpikir kritis matematis pada model pembelajaran Problem Based Learning, yaitu kemampuan siswa dalam memahami masalah dalam soal cerita masih rendah sehingga sering mengalami kesulitan dalam mengubah bentuk masalah menjadi model matematika. Sedangkan penyebab rendahnya rata-rata hasil tes kemampuan berpikir kritis matematis pada pembelajaran model Reciprocal Teaching dikarenakan siswa terbiasa mendapatkan sebuah konsep, pola, atau hubungan antarkonsep dalam matematika oleh guru, sehingga ketika siswa dituntut untuk mengetahui dan mempelajari hal tersebut sendiri, siswa sering merasa kesulitan.

Proses pembelajaran model Problem Based Learning dilakukan dengan cara siswa diberikan suatu masalah yang akan diselesaikan secara berkelompok. Pemberian permasalahan dimaksudkan agar siswa mengetahui hubungan pengetahuan yang dimilikinya dengan penerapannya dalam kehidupan sehari-hari sehingga pembelajaran matematika lebih terasa bermakna bagi siswa. Pemberian latihan soal ini bertujuan agar siswa mulai terbiasa menjawab soal-soal kemampuan berpikir kritis matematis.

Proses pembelajaran model Reciprocal Teaching dilakukan dengan cara memberikan contohcontoh atau suatu permasalahan matematika kepada siswa seingga memungkinkan siswa mencari dan menemukan sendiri konsep, pola, atau hubungan antarkonsep dalam matematika melalui bimbingan dari guru. Bimbingan dari guru membantu siswa dalam belajar menggunakan model Reciprocal Teaching.

\section{KESIMPULAN DAN SARAN}

\section{A. Kesimpulan}

Berdasarkan hasil penelitian dapat disimpulkan bahwa kemampuan berpikir kritis matematis siswa yang belajar menggunakan model Problem Based Learning lebih tinggi dari kemampuan berpikir kritis matematis siswa yang belajar menggunakan model Reciprocal Teaching pada materi garis singgung lingkaran di kelas VIII pada SMP Negeri 149 Jakarta.

\section{B. Saran}

Berdasarkan hasil dari penelitian ini, terdapat beberapa saran yaitu sebagai berikut:

1. Pembelajaran menggunakan model Problem Based Learning dan model Reciprocal Teaching memerlukan waktu yang relatif lama dalam proses pembelajarannya, sehingga diperlukan perencanaan dan persiapan yang matang sebelum diterapkan dalam pembelajaran di kelas, agar proses pembelajaran dapat berjalan sesuai dengan tujuan pembelajaran yang akan dicapai.

2. Guru dalam pelaksanaan dengan model diskusi diharapkan memperhatikan peran siswa dalam kelompok masing-masing agar seluruh siswa dapat berpartisipasi aktif dalam proses pembelajaran matematika di kelas.

3. Untuk peneliti selanjutnya, sebaiknya menggunakan lembar observasi atau catatan lapangan untuk mendukung dan memperkuat data statistik yang diperoleh.

\section{DAFTAR PUSTAKA}


Abdul Rahman, dkk. (2014). "Teaching Problem Solving in Mathematics Learning: Reflection from PISA and TIMSS Results of The Students of Indonesia." Proceeding of International Conference On Research, Implementation and Education of Mathematics and Sciences. Yogyakarta: Universitas Negeri Yogyakarta.

Karim, A. (2010). Meningkatkan Kemampuan Berpikir Kritis Melalui Model Recprocal Teaching . Jakarta: Universitas Pendidikan Indonesia.

NCTM. (2000). "Principles and Standards for School Mathematics." Online. http://www.nctm.org/Standards-and-Positions/Principles-and-Standards/. Diakses 15 Juni 2015.

Noer, S. H. (2009). "Peningkatan Kemampuan Berpikir Kritis Matematis Siswa SMP melalui Pembelajaran Berbasis Masalah." Makalah. Yogyakarta: Universitas Negeri Yogyakarta

Shoimin, A. (2014). 68 Model Pembelajaran Inovatif dalam Kurikulum 2013. Yogyakarta: Ar-Ruzz Media.

Somakim. (2012). "Peningkatan Kemampuan Berpikir Kritis Dan Self-Efficacy Matematik Sekolah Menengah Pertama Dengan Penggunaan Pendekatan Matematika Realistik." Tesis. Bandung: Universitas Pendidikan Indonesia.

Sudjana. (2005). Metoda Statistika. Bandung: Tarsito.

Sugiyono. (2009). Statistika untuk Penelitian. Bandung: Alfabeta. 